\title{
SOCIALIZATION OF THE USE OF GROUNDWATER IN THE SOUTH MERUYA REGION OF WEST JAKARTA
}

\author{
Acep Hidayat ,Suprapti, and Soh Aly \\ Universitas Mercu Buana Jakarta, Indonesia \\ Union of The Youth Federation of Cambodia, Cambodia.
}

\begin{abstract}
With the growth of the city every year, it changes the composition of land use. City growth that occurs in line with the development of population, social activities and industrial activities that accompany it, resulting in increased demand for land availability that will be used to carry out various activities. The availability of land as a media for water absorption is decreasing while the use of ground water is continuously being explored to meet the needs of the community, social activities and industrial activities. Structure and texture as well as other organic elements take part in increasing the rate of soil permeability The use of ground water by the community and social activities is not greater than the use by industrial activities. At present, especially large cities with very rapid development of industrial activities are causing large groundwater usage. With the decreasing availability of infiltration land, making the process of water entering the soil less and less, if this happens continuously in the long run, it will cause a decrease in the ground water level, a decrease in land elevation, and easy sea water instruction. Therefore it is necessary to socialize to the public about the use of ground water so that the condition of groundwater is maintained.
\end{abstract}

Keyword : Land Use, Population, Absoption, Infiltration Land, Groundwater

\section{BACKGROUND}

The theory that water that seeps into the ground must be balanced with the amount of groundwater uptake. Ground water is water that is below the surface of the earth. The main source of rain water that seep down through the pore space between the grains of soil. Water greatly influences the technical properties of soils, especially fine-grained soils. Likewise water is a very important factor in issues such as settlement, foundation stability, slope stability, etc. (7)

For soil, permeability is described as the nature of the soil which drains water through the pore cavities of the soil. In soil, flow properties may be laminar or turbulent. Resistance to flow depends on soil type, grain size, grain shape, mass density, and geometrical shape of the pore cavity (8). Temperature also greatly influences the resistance of flow (viscosity and surface tension. All types of soil are water-permeable) where free water flows through the empty spaces (pores) that exist between soil grains. Pore pressure is measured relative to pressure the atmosphere and the surface layer of the soil whose pressure is the same as the atmospheric pressure is called the ground water level or freasik surface, below the ground water level.The soil is assumed to be saturated even though it is not so because there are air cavities. Structure and texture as well as other organic elements take part in increasing the rate of soil permeability, soils with high permeability increase the rate of infiltration and thus, decrease the rate of runoff water, groundwater levels vary according to climatic conditions but can also change due to influence from construction activities.

In that place can also occur shallow ground water level, above the normal ground water level, while the conditions can occur if the soil with high permeability on the upper surface is limited by the local ground water level, but based on ground water level in another place with layers the top is not limited by a dense layer of water. The permeability coefficient mainly depends on the average pore size that is affected by the particle size distribution, particle shape and soil structure (6). Broadly speaking, the smaller the particle size, the smaller the pore size and the lower the coefficient of permeability. Means a coarse grained soil layer containing fine grains has a lower $\mathrm{k}$ value and in this soil the permeability coefficient is a function of the pore number. If the soil has layers of permeability for parallel flow is greater than permeability for perpendicular flow. The permeability layer of the cleft clay is larger than the unfissured clay. This permeability is a measure of ease of flow through a poreus media (11). Quantitatively permeability is limited by the coefficient of permeability. Many researchers have examined the permeability problem and developed several formulas that can be seen as typical 
contributions. The intrinsic permeability of an aquifer depends on the effective porosity of rocks and unconsolidated materials, and the free space created by fractures and solutions. Effective porosity is determined by the grain size distribution, shape and roughness of each particle and their combined arrangement, but because these properties are rarely uniform, the hydraulic conductivity of a developing aquifer is limited by the permeability of layers or individual zones, and may vary considerably large depends on the direction of water movement (13).

\section{PURPOSE}

In this community service activity aims:

- Providing education to the community about clean living.

- Give direction to the importance of drainage channels

- Build drainage channels in areas where drainage is minimal.

The benefits to the community from this community service are:

- Communities can understand the causes of floods in their area and how to solve them.

- Make the community aware of the importance of Healthy Living and a Clean Environment.

- Educate the public about flood anticipation.

\section{METHOD APPLICATION}

The mechanism of the implementation of the Community Service activities includes the following stages:

1. Coordinate with the community and non-governmental organizations. Carried out by the implementers of community service. Coordination is carried out in the context of a request for willingness as well as discussing problems faced by the community.

2. Preparing material to be delivered to the public. The preparation and debriefing materials provided to the community include the following:

- The active role of the community in community service activities

- Explanation of Drainage Network problems in South Meruya Region.

In its implementation, the program carried out several stages, namely:

1. Dissemination of water drainage systems. In this activity, the community is given guidance to be able to create a good water management system.

2. The importance of the dissemination of drainage canals.

3. Socialization to the community to be able to live clean and healthy.

\section{RESULT}

From the results of research conducted in several places in the South Meruya region which states the rate of infiltration for the Meruya area is small with the type of clay so that the flow that occurs on the surface is greater than the water that seeps into the ground. Conducting soil sampling in several locations in the Meruya Selatan Kelurahan area.

The documentation of the implementation of Hand Boring is as follows:
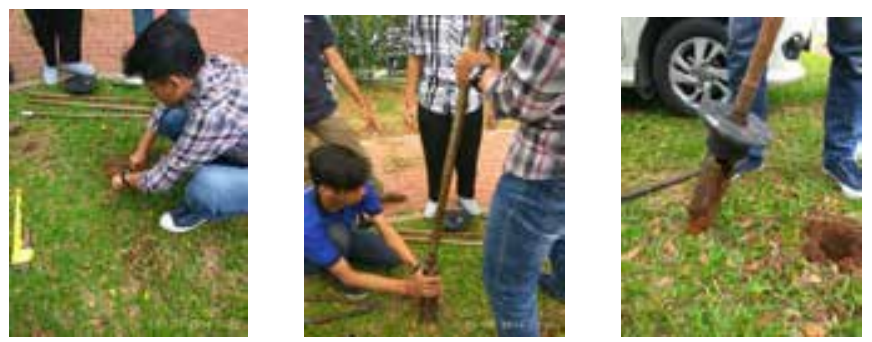

Picture 1: Implementation of the Boring hand

From this result socialization was carried out to the community through social institutions located in the area of South Meruya Village. With this expectation, the public can use groundwater in accordance with the needs and means of drainage infrastructure in accordance with the flow that occurs on the surface. 

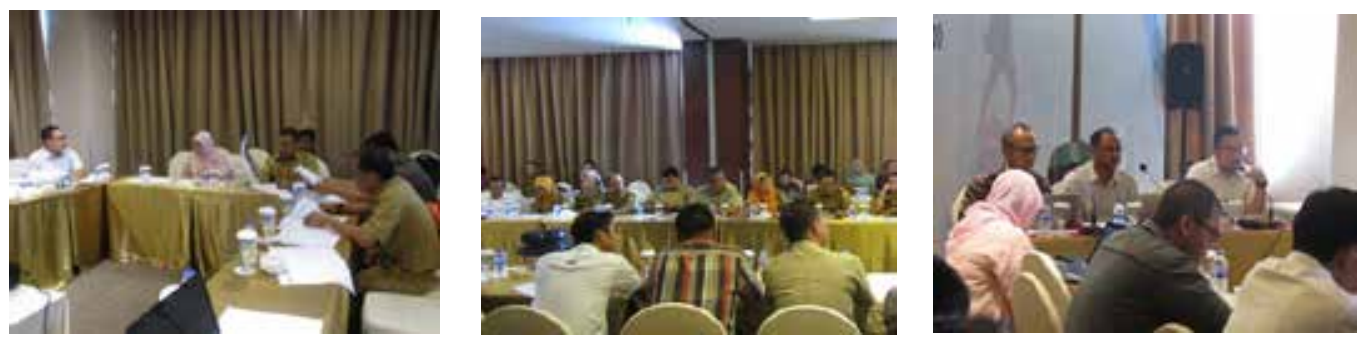

Picture 2: Socialization with Community Institutions.

\section{CONCLUSION}

1.With very small seepage discharges, media are needed to increase the absorption capacity of water such as recharge wells, Biopori and reservoirs to maintain ground water stability.

2. Adding drainage facilities and infrastructure in the South Meruya region.

3. Addition of Green open spaces.

\section{REFERENCES}

Chrismadha, T. 2008. Conservation of Water Resources. www.opi.lipi.go.id, March 11, 2012.

Chow, Ven Te., 1985, Open Channel Hydrology, Erlangga Publisher, Jakarta

Karnanto., And Loebis J, 1980, Calculation of the Maximum Rainfall Method Gumbel and Probable Maximum Precipitation, Directorate for Investigation of Problems Water, Bandung. Control in the Environmental Perspective, Student Library, Yogyakarta.

Loebis, J., 1987. Flooding Plans For Water Buildings, Department of Works General, Public Works Publishing Agency, Jakarta.

Soemarto, CD., 1999, Technical hydrology, Edition Two, Erlangga, Jak 